\title{
PROF. DR HAB. MICHA£ KACZMARKOWSKI JAKO BADACZ ŁACINY WCZESNOCHRZEŚCIJAŃSKIEJ
}

(1934-2003)

Michał Kaczmarkowski urodził się w Lesznie Wielkopolskim (woj. leszczyńskie), gdzie w 1948 r. ukończyl siedmioklasową szkołę podstawową, a w maju 1952 r. zdał po ukończeniu czteroletniego miejscowego liceum ogólnokształcącego egzamin dojrzałości. Odbył podwójne studia: teologiczne i filologiczne. Dnia 20 stycznia 1960 r. uzyskał w Katolickim Uniwersytecie Lubelskim tytuł magistra teologii w dziedzinie teologii dogmatycznej na podstawie studiów w Arcybiskupim Wyższym Seminarium Duchownym w Gnieźnie i w Poznaniu oraz pracy pt. Stosunek Chrystusa Pana do Kościoła $w$ świetle pism św. Ireneusza z Lyonu, napisanej pod kierunkiem ks. prof. Wincentego Granata. W latach 1952-1957 studiował filologię klasyczną w Katolickim Uniwersytecie Lubelskim, którą ukończył uzyskaniem tytułu magistra w zakresie filologii klasycznej w oparciu o prace pt. Cyceron - Listy do Tyrona: wstęp, komentarz, przekład, którą kierował starszy wykładowca dr Marian Nagnajewicz. Dnia 29 kwietnia 1971 r. uzyskał stopień doktora w zakresie filologii klasycznej na Wydziale Filologicznym Uniwersytetu Adama Mickiewicza w Poznaniu na podstawie rozprawy pt. Składnia przytoczenia $w$ tekstach prozaików lacińskich okresu klasycznego, opublikowanej drukiem w 1974 r. przez Towarzystwo Naukowe KUL; jej promotorem był prof. dr hab Michał Swoboda. Stopień doktora habilitowanego nauk humanistycznych w zakresie językoznawstwa ogólnego nadala mu Rada Wydziału Nauk Humanistycznych KUL na podstawie dorobku naukowego i pracy habilitacyjnej pt. Nominalne grupy syntaktyczne taciny okresu klasycznego, opublikowanej później w 1985 r. w Redakcji Wydawnictw KUL. Kolokwium habilitacyjne odbyło się w dniu 19 października 1983 roku. Uchwałę Rady Wydziału Nauk Humanistycznych KUL zatwierdziła Centralna Komisja Kwalifikacyjna do Spraw Kadr Naukowych przy Prezesie Rady Ministrów pismem z dnia 29 października 1984 roku.

Michał Kaczmarkowski przechodził stopniowo kolejne angaże na Katolickim Uniwersytecie Lubelskim. W roku uzyskania magisterium z wyróżnieniem został zatrudniony jako młodszy asystent przy Zakładzie Filologii Klasycznej, a od paź- 
dziernika 1965 r. do września 1971 r. jako starszy asystent przy Zakładzie Językoznawstwa Ogólnego. Po uzyskaniu doktoratu od października 1971 do października 1985 r. był adiunktem przy Zakładzie Językoznawstwa Ogólnego KUL. W oparciu o zatwierdzone przez Ministra Nauki i Szkolnictwa Wyższego w dniu 18 października 1985 r. stanowisko docenta Rada Wydziału Nauk Humanistycznych KUL powołała go 4 grudnia tegoż roku na kierownika Katedry Językoznawstwa Ogólnego KUL, co zostało przyjęte przez Senat Akademicki KUL dnia 11 stycznia 1986 roku. Z dniem $1 \mathrm{kwietnia} 1992 \mathrm{r}$. został zatrudniony na stanowisku profesora nadzwyczajnego i pozostał na nim aż do przejścia na emeryturę w lutym 2001 roku. W czasie swej 39-letniej pracy naukowo-dydaktycznej wśród wielu funkcji, jakie pełnil w KUL, był też w latach 1987-1989 prodzickanem Wydziału Nauk Humanistycznych, a od r. 1986 do 2001 czlonkiem Rady Naukowej Redakcji „Vox Patrum”. Za swoją pracę naukową, niezwykle zaangażowanie dydaktyczne i prawą postawę moralną został 2 marca 2001 r. uczczony przyznanym mu przez Senat Akademicki KUL Medalem za zastugi dla Katolickiego Uniwersytetu Lubelskiego.

Zainteresowania i badania naukowe prof. Michała Kaczmarkowskiego dotyczą niezmiennie przede wszystkim dwu dziedzin: językoznawstwa łacińskiego i językoznawstwa ogólnego. W ramach pierwszej dziedziny jego zainteresowania koncentrują się głównie wokół składni opisowej, a ramach drugiej - dotyczą zwłaszcza skladni ogólnej, jaką prezentuje gramatyka zależności. Nieobce mu też były zagadnienia metodologii i problemowo ujmowanej historii językoznawstwa ogólnego.

Prof. Michał Kaczmarkowski współpracował także z Międzywydzialowym Zakładem Badań nad Antykiem Chrześcijańskim KUL oraz Sekcją Filologiczną przy Komisji Episkopatu Polski do Spraw Nauki, gdzie na organizowanych przez te instytucje sympozjach i zjazdach wygłaszał nierzadko prelekcje, najczęściej z zakresu językoznawstwa łacińskiego. I tak np. we wrześniu 1968 r. wygłosił na spotkaniu Sekcji Filologicznej w Wyższym Seminarium Duchownym w Sandomierzu referat na temat: Historia języka lacinskiego od czasów najdawniejszych do dziś, który później ukazal się drukiem ${ }^{1}$, zaś 25 maja 1972 r. w Metropolitalnym Seminarium Duchownym w Gnieźnie na Sympozjum patrystycznym zorganizowanym przez Międzywydziałowy Zakład Badań nad Antykiem Chrześcijańskim KUL, przedstawił w formie szkicu informacyjnego istotę, charakterystykę, rozwój i problemy badawcze laciny chrześcijańskiej². Starochrześcijańską łacinę określał za prof. J. Schrijnen jako specjalny język pierwszych chrześcijan, a za Ch. Mohrmann dodawał, że łacina starochrześcijańska wykazuje pewną sumę odmienności, które pod wpływem chrześcijańskiego poglądu na życie jako czynnika różniącego zaistniały w ramach języka ogólnego. Lacina chrześcijańska - stwierdza prof. Kaczmarkowski - różni się od późno-

${ }^{1}$ Por. M. Kaczmarkowski, Historia języka laciniskiego od czasów najdawniejszych do dziś, VoxP 6 (1986) z. 11, 477-504.

2 Por. M. Kaczmarkowski, Łacina starochrześcijańșka (istota, charakterystyka, rozwój, problemy badawcze), RTK 26 (1979) z. 4, 35-44; wcześniej w r. 1970 wygłaszał referaty na sympozjach Zakładu w Warszawie (8-9 V): Teoria przekładu-przedmiot, problematyka i miejsce wśród innych nauk, oraz w Lublinie (5-6 XI): Nieprzekładalność jako problem językowy, a także prowadzil konwersatorium na temat wybranych listów Cycerona. 
łacińskiego języka ogólnego słownictwem, stroną znaczeniową, słowotwórstwem i składnią. Do laciny chrześcijańskiej weszły także zjawiska stylistyczne, jak: niezwykła obrazowość i silne zabarwienie uczuciowe stylu. Łacina chrześcijańska ma swoje chrystianizmy: leksykalne, semantyczne, słowotwórcze i syntaktyczne. Tak rozumiana łacina starochrześcijańska powstała ok. poł. II wieku. Tworzyli ją najpierw ludzie prości, zwyczajni członkowie gmin chrześcijańskich na Zachodzie, potem pierwsi tłumacze Biblii na łacinę, wreszcie pisarze wczesnochrześcijańscy i Ojcowie Kościoła. Na charakter zjawisk językowych łaciny chrześcijańskiej miała wpływ okoliczność, że chrześcijaństwo znalazło najpierw swój wyraz w świecie hebrajskim i greckim, a później dopiero w świecie łacińskim. Ponadto ważniejsza dla chrześcijan była treść doktrynalna niż język, który traktowali świadomie jako narzędzie głoszenia dobrej nowiny. Bujny i żywiołowy rozwój łaciny starochrześcijańskiej - stwierdza nasz Badacz laciny wczesnochrześcijańskiej - trwal do początków IV wieku, kiedy to coraz więcej wykształconych pogan przyjęło chrześcijaństwo. Oni już zajmują wobec łaciny starochrześcijańskiej postawę bardziej purystyczną i zachowawczą. Niekwestionowanym wzorem staje się także Biblia lacińska, której piękno języka i stylu wykazywał św. Augustyn. Łacina chrześcijańska powoli z języka specjalnego stawała się językiem ogólnym, tak ze nawet pisarze pogańscy czerpali nierzadko zapożyczenia $z$ laciny chrześcijańskiej.

Nieco później 25 września 1984 r. na dorocznym zjeździe Sekcji Filologicznej w Lublinie mial odczyt pt. Jezzykoznawstwo konfrontatywne a nauczanie taciny ${ }^{3}$, a potem 14 września 1987 r. w Wyższym Seminarium Duchownym wykład pt. Wykorzystanie teorii konotacji syntaktycznej czasownika w nauczaniu taciny ${ }^{4}$. Na uwagę zasługuje tu też artykul: Język i styl św. Benedykta ${ }^{5}$, który jest niezmienioną wersją referatu wygłoszonego 25 września 1982 r. w klasztorze OO. Oblatów na Świętym Krzyżu na dorocznym zjeździe Sekcji Filologicznej. Autor stwierdza w nim, że łacina Reguly św. Benedykta to łacina potoczna VI wieku, ale „to nie znaczy niepoprawna, lecz taka, jaką mówiły ówczesne warstwy wykształcone społeczeństwa rzymskiego, trzymając się $z$ dala od sztywnych, pedantycznych, zbyt tradycyjnych i zbyt normatywnych reguł nauczanych przez szkołę, opierających się na wzorach klasycznych [...]. W ramach łaciny późnej, łaciny żywej, łaciny VI wieku jest to zarazem, w swej odmianie środowiskowej, lacina chrześcijańska, a w jej obrębie - łacina monastyczna czy z silnymi wpływami monastycznymi, więc język specjalny jeszcze węższej, kształtującej się już od kilku wieków w obrębie chrześcijaństwa, grupy socjalnej - zakonników" (s. 156). Profesor dodaje, że wskutek swej chrześcijańskości i monastyczności język ten wykazuje również silne wpływy języka biblijnego, mówiąc zaś o stylu

${ }^{3}$ Por. M. Kaczmarkowski, Jezykoznawstwo konfrontatywne a nauczanie laciny, VoxP 6 (1986) z. 10, 61-71.

${ }^{4}$ Por. M. Kaczmarkowski, Wykorzystanie teorii konotacji syntaktycznej czasownika w nauczaniu taciny, VoxP 8 (1988) z. 14, 435-450.

${ }^{5}$ Por. M. Kaczmarkowski, Język i styl św. Benedykta, RTK 29 (1982) z. 4, 149-165; lub: Zur Textstruktur der Moenchsregel des hl. Benedikt von Nursia, w: Aevum inter utrumque, The Hague 1991, 277-287; La struttura del testo della Regola di San Benedetto da Norcia, „L'analisi linguistica e letteraria" 2 (1994) 301-313. 
Reguly św. Benedykta, idzie za Krystyną Mohrmann, określając go jako: bardzo męski, żywy, prosty, trzeźwy, lapidarny, chwilami prawniczy, często nader osobisty, żarliwy, ale nie pozbawiony pewnej hieratyczności i sakralności (s.157).

Łacinie wczesnochrześcijańskiej poświęcił prof. Kaczmarkowski również artykuł pt. Struktura pionowa tekstów: Passio Sanctarum Perpetuae et Felicitatis, Passio Sanctorum Mariani et Iacobi i Passio Sanctorum Montani et Lucii ${ }^{6}$. Autor podsumowując przeprowadzoną przez siebie analizę tekstów stwierdza, że podobieństwa występujące między omówionymi Passiones, ,nie wykraczają swym stopniem czy charakterem poza ramy zbieżności przypadkowych lub, co najwyżej, zbieżności, będących następstwem jedynie umiarkowanego $\mathrm{z}$ jednej strony wpływu bezwiednego, a z drugiej świadomego naśladownictwa" (s. 218).

Nie można tu też nie wspomnieć zorganizowanego w Zakładzie Badań nad Antykiem Chrześcijańskim spotkania thumaczy pism św. Augustyna, któremu przewodniczył wlaśnie prof. Kaczmarkowski. W sprawozdaniu ${ }^{7}$ stwierdził, że w przypadku dzieł Biskupa Hippony dobry thumacz winien być zarazem dobrym filologiem i dobrym teologiem. Gdyby obu tych właściwości tłumacz nie mial, należałoby przed oddaniem przekładu do druku poddać go odpowiedniej konsultacji i weryfikacji ze strony teologa. Profesor Kaczmarkowski nie tylko zrecenzowal pierwszy polski przekład De Trinitate św. Augustyna ${ }^{8}$, ale sam jest autorem wielu znakomitych thumaczeń i to nie tylko z jçzyków klasycznych, ale także $\mathrm{z}$ laciny chrześcijańskiej ${ }^{9}$, jak i kilkanastu artykułów o tematyce teologicznej z języków zachodnioeuropejskich, które ukazywały się w "Concilium” oraz dwóch pozycji książkowych w kolekcji „Znaki Czasu”, wydawanej w języku polskim przez Editions du Dialoque: Joseph Moeller, Człowiek $w$ świecie. Zarys antropologii filozoficznej, Paris 1969 oraz S. Teresa Renata od Ducha Świętego, Edyta Stein - Siostra Teresa Benedykta od Krzyża, filozof i karmelitanka, Paris 1973.

Wydaje się, że nie można w tym miejscu nie wspomnieć, że prof. Kaczmarkowski był też czlonkiem Komisji nowego tłumaczenia dokumentów Soboru Watykańskiego II, które ukazało się drukiem w 2002 r., a w nim autorem przekładu deklaracji o wolności religijnej Dignitatis humanae.

Pod kierunkiem Profesora Kaczmarkowskiego powstały też obok innych prac magisterskich, także dwie z literatury patrystycznej: W. Woźniak: Sulpicjusz Sewer, Żywot św. Marcina. Wstęp, przekład, komentarz (1985) oraz J. Kosalla: Acta Martyrum. Wstęp, thumaczenie, komentarz (1987). Obie prace dotyczą języka laciny chrześ-

${ }^{6}$ Por. M. Kaczmarkowski, Struktura pionowa tekstów: Passio Sanctarum Perpetuae et Felicitatis, Passio Sanctorum Mariani et lacobi i Passio Sanctorum Montani et Lucii, VoxP 11-12 (19911992) z. 20-23, 213-221.

${ }^{7}$ Por. M. Kaczmarowski, Spotkanie thumaczy pism św. Augustyna, VoxP 8 (1988) z. 14, 485 487.

${ }^{8}$ Por. M. Kaczmarkowski, rec: Pierwszy polski przekład „De Trinitate” św. Augustyna (Sw. Augustyn, O Trójcy Swiętej, przekład M. Stokowska, oprac. J.M. Szymusiak, Poznań 1963, POK 25), ZN KUL 8 (1965) nr 4, 75-77.

${ }^{9} 9$ Por. Sw. Maksym z Turynu, Przygotowanie do Świq̨t Narodzenia Pańskiego (Mowa 60), w: Kazania i homilie na święta Pańskie i Maryjne, STCh 1, red. L. Gładyszewski, Lublin 1976, 31-34. 
cijańskiej. Recenzję pierwszej z nich umieścił Profesor w „Vox Patrum”10. Za najcenniejsze w tej pracy promotor uważa uwagi o tzw. chrystianizmach, czyli - według szkoły z Nijmegen Schijnena i Mohrmann - o elementach typowo chrześcijańskich w łacinie późniejszej.

Z pobieżnego przeglądu publikacji Profesora Michała Kaczmarkowskiego wyraźnie wynika, że jego prace badawcze nie ograniczały ściśle do laciny klasycznej, ale sięgały również łaciny wczesnochrześcijańskiej z nachyleniem się ku teologii, co wiązało się $\mathrm{z}$ jego nader prawą postawą moralną.

Ks. Augustyn Eckmann - Lublin, KUL

${ }^{10}$ Por. VoxP 7 (1987) z. 12-13, 469-470. 